\title{
骨転移を初発症状としたがん患者についての検討
}

$\begin{array}{cccc}\text { 国立がんセンター } & \text { 整形外科 } & \\ \text { 前 } & \text { 山 } & & \\ \text { 佐 } & \text { 藤 } & \text { 三 } & \text { 郎 } \\ \text { 後 } & \text { 藤 } & & \text { 将 }\end{array}$

\section{Observations on the Cancer Patients with Bone Metastasis which was the First Manifestation of the Cases}

By

\author{
I. Maeyama, S. Sato \& S. Goto \\ Bone Tumor Service, National Cancer \\ Center Hospital
}

\begin{abstract}
Twenty-seven cases of cancer patients with bone metastases which resulted in the first manifestation were recognized at the National Cancer Center Hospital of Japan, from March 23rd, 1962 to December 28th, 1965.

Among them 10 cases have primary site in bronchus, unknown in 7 cases, 5 in kidney 3 in prostate, 1 in thyroid, 1 in liver, and remaining 7 cases were not diagnosed their primary site with any of the clinical and cytological examination and autopsy.

4 cases, in which primary lesions were each of bronchus, kidney, prostate and liver, were demonstrated as the very interesting cases with regards to the diagnosis and treatment of the primary lesions and their bone metastases.

Especially, in case of the bone metastasis of cancer of kidney radical nephrectomy was postulated to be performed if possible, despite of the evidence of wide-spread bone metastasis.
\end{abstract}

覀性腫瘍において骨転移症状か原発巣の症状に先行 して出現することは決して稀なすのではなく, 特に発 生頻度の多いがんの骨転移では従来その約 $8 \%$ から 16\%が原発巣不明, あるいは骨転移症状を初発症状之 すると報告されているが, 今度, がんセンターにおい て 3 年 7 ケ月の間に骨転移を初発症状としたがん患者 27 症例について検討する機会を得たので, とこに報告 する.

27 例の原発がんの種別は肺がん 10 例, 原発不明が ん 7 例, 腎臟がん 5 例, 前立腺がん 3 例, 甲状腺がん および肝臟がんがそれぞれ 1 例で, 肺がんと腎臟がん が略々半数以上を占めている(表 1 ).

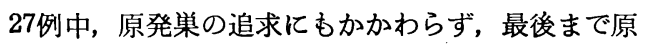
発巣が発見できなかつた 7 例のほかは 20 例中 17 例が その臨床経過中に肺細胞晾, 腎臓動脈撮影などにより 原発がんが確認され適切な治療が行なわれているが,

\section{表 1 骨転移を初発症状としたがん患者}

\begin{tabular}{|c|c|c|c|}
\hline $\begin{array}{l}1 . \\
2 . \\
3 . \\
4 . \\
5 . \\
6 .\end{array}$ & $\begin{array}{l}\text { 肺 } \\
\text { 原 } \\
\text { 腎 } \\
\text { 前 } \\
\text { 甲 } \\
\text { 肝 }\end{array}$ & 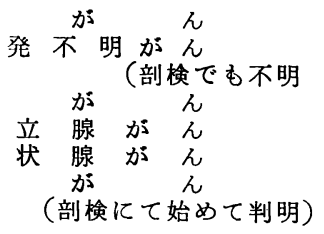 & $\begin{array}{l}10 \text { 名 } \\
7 \\
3) \\
5 \\
3 \\
1 \\
1\end{array}$ \\
\hline & 総 & 計 & 27 \\
\hline
\end{tabular}

20 例中肺がん 2 例之肝臟がん 1 例は死後剖検で始めて 原発がんが発見された。

以上 27 症例中, 特江興味ある症例と考えられる腎 臟がん, 肺がん, 前立腺がんおよび原発性肝臓がんの 骨転移初発例について, その臨床経過, 特に原発㢼の 診断と原発巣扰よび骨転移巣の治療について，以下若 干の検討考察を試みる. 


\section{症}

例

症例 160 才, 男子.

主訴 腰痛.

現病歴 昭和 40 年 6 月, 何ら誘因なく腰痛が起り, 種々の対症療法を行うも効なく, 腰痛は徐々に増強し 12月末には右下肢の激痛む加わり, 歩行不能となり夜 間も疼痛のためほとんど睡眠むとれなくなつたので, 41年 1 月, 某国立病院に入院し, レ線検査の結果仙骨 部および両腸骨部に溶骨性の病変を発見され, 恐らく がんの骨転移であろうとの診断のもとに ${ }^{60} \mathrm{Co}$ 照射を 22 回受けたが腰痛が軽減しないので 3 月10日, 当科に 入院した.

入院後経過 入院後直ちに全身骨撮影を行うに, 仙 骨, 両腸骨, 左恥骨および右大腿骨々幹部に著明な溶 骨像が認められ，また右上腹部に肝蔵に接して比較的 硬い腫瘤が触知されたので, グラヴィツ腫演を疑い,

3 月24日, Aortography による腎臓の動脈撮影を施 行するに，右䐌下極は腫瘍によつて血管の走行が完全 そ破壊され，腫㴦はかなりの大きさに達し相当広範な 壊死巣を伴つていると推定された．3月15日より 5 月 6 日までにリニアック総量 $6,050 \mathrm{rads}$ を骨転移巣に 照射し，6月 3 日，全身状態の改善を確認して右腎蔵 摘除, 右副腎摘除およびリンパ節廓清術を施行した が, 腫瘍の肉眼所見は腎臓の動脈撮影の所見と一致し ており, 組織像む典型的な clear cell carcinoma で あつた. 41年 6 月19日, 腎摘之骨転移巣のリニアック 照射の効果を期待して退院したが, 10月14日現在, 骨 転移巣のレ線像はほとんど不変であるが，腰痛は著し く軽減し, どうにか松葉杖歩行も可能となつている.

症例 2 55才, 女子.

主訴 左肩関節痛.

現病歴 昭和 40 年 5 月, 左脛骨部に腫瘤が出現し, 同年 8 月某医大にて 腫瘤部の 局所 ブロック 切除を受 け，骨の転移性腺がんと判明したが原発巣は不明であ つた. 10月に至ると更に激烈な左肩関節痛が起り、レ 線撮影で左肩胛骨に溶骨性の転移像が発見されたので 11月11日当科に入院した(写真 1 ).

入院後経過 数年前加ら陳旧性肺結核之診断されて きたという右肺下葉の拇指頭大の異常陰影部の肺細胞 診を施行するに, 癌細胞が検出され, 恐らく腺がんと 考えられ，また肩胛骨部の $\mathrm{Sr} 85$ によるシンチグラム でも転移巣部に一致して $\mathrm{Sr} 85$ の摄取が認められ, 右

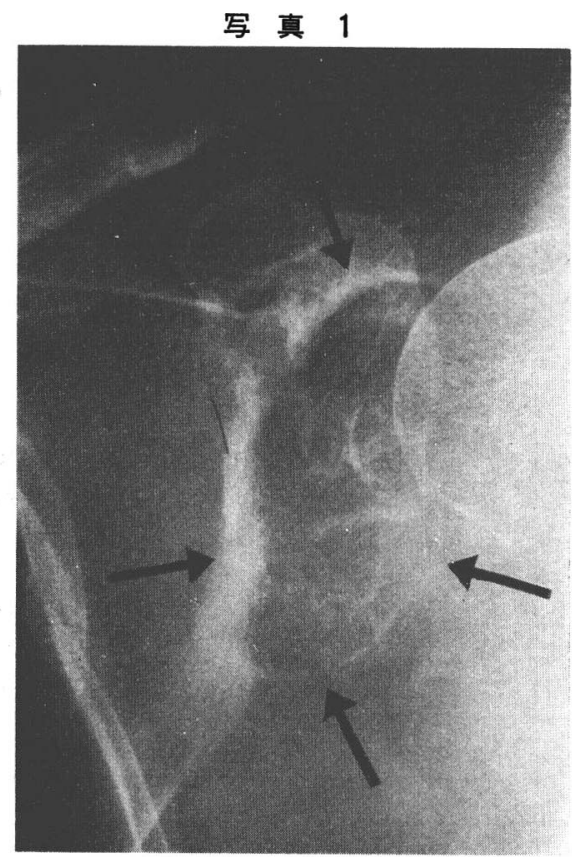

症例 2 55才，女，肺がんの左肩胛骨転移

肺下葉原発の肺がんの骨転移と確診されたので, 直ち に肺の原発巣および肩胛骨の転移巣にリニアック照射

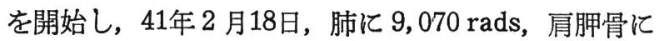
10,100 rads の放射線療法を終了したが，肩関節痛は 殆んど消失し，その上，レ線学的にむ肩胛骨に著明な 骨硬化像の出現が認められたので，4 月13日近医に経 過観察を依頼して退院したが 41 年 9 月現在, 肺には がん再発の徵はないが放射線肺炎像が著明である.

症例 366 才, 男子.

主訴 腰痛.

現病歴 昭和 40 年 8 月, 腰痛のため当院に来院し, レ線撮影で第 4 腰椎, 左仙腸関節周辺部および両大腿 骨近位メタフィーゼ部に骨形成性の病変が発見され, 血液化学所見ですアルカリおよび酸性ホスファターゼ 值の上昇が認められ，特に酸性ホスファターゼ值は 4.7 以上と著しい上昇を示しており, 前立腺がんの骨 転移が疑われ9月14日当院に入院した。

入院後経過 骨転移巣に対してリニアックとテレコ バルト照射を 9 月29日から開始し, 10月 6 日除睪術と 前立腺の試切を施行し, 前立腺がんの骨転移と確診さ れたので 10月11日よりホンバン $600 \mathrm{mg}$ 内服を併用し 12 月22日, リニアック総量 $3,240 \mathrm{rads}$, テレコバルト 
総量 4,650 rads 照射を終了し，12月30日退院し, 以 後外来にて経過観察中であるが, 41 年 9 月現在, 腰痛 は全く軽快し血液化学所見でもアルカリおよび酸性ホ スファターゼ值は略々正常域に復しているが, 骨転移 巣のレ線所見では骨形成像が相当進行してきている。

症例 4 58才, 男子.

主訴 右側胸部の腫瘤形成と左大腿部の変形.

現病歴 昭和 39 年 6 月, 右第 10 肋骨部に相当して固 い拇指頭大の腫瘤が出現し, 他院にて切除術の結果, 肋骨の転移性腺がんと判明したが 7 月 21 日左大腿骨の 病的骨折をむ起としたので 7 月 31 日当院に入院した (写真 2 ).

写 真 2

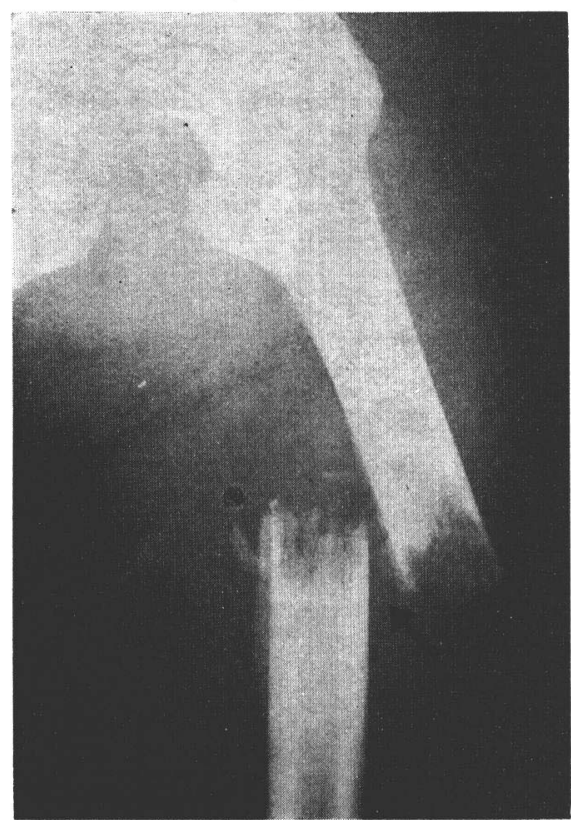

症例 4 58才, 男, 肝がんの左大腿骨 転移に上る病的骨折

入院後経過 入院後直ちにキュンチャー釘による骨 接合術施行の上，原発巣探索のため種々の検查を行つ たが, 何ら異常を認め得ないまま, 8 月10日癌性腹膜 炎を起てし，9月23日死亡したので剖検を行つたとて ろ, 左葉原発性肝がんの骨転移であつたととが判明 した.

考按

がんの骨転移巣の症状が原発巣の症状に先行して出
現したり，あるいは種々の方法による原発巣の探索に あかかわらず，原発巣が未発見のままに経過するとと は我々もしばしば経験するととであるが，てれら骨転 移患者の原発巣の猃断や治潦化関して未だ綜合的な考 察抢よび検討は内外の文献にも少く，むし万等閑視さ れてきた傾向さえ見られるようである.

骨転移を初発症状とした患者の頻度について文献学 的洘察すれば, Graham は 1,550 例中 129 例 (8.3 $\%$ ), Geschickter らは 356 例中 60 例 (16.8\%), 菊 屋は 110 例中 48 例 $(43.6 \%)$ と報じている. 菊屋は 原発巣が未発見のままに経過したすのは 110 例中 18 例 (16.3\%) で骨転移初発例で原発巣がその後の諸検 查で発見されたすのは特に肺がんと腎がんに多く、つ いで甲状腺がんと前立腺がんであつたと報じておらり, Geschickter らは骨転移初発例 60 例中 22 例 (36.6 \%）が腎がんの骨転移であつたと報じている.

国立がんセンターにおいては昭和 39 年12月末までに 225 例の骨転移患者が発見されているが，そのうち， 骨転移初発例は 16 例 (7.1\%) である. 原発臓器別で は肺がん 36 例中 4 例 $(11.1 \%)$, 腎がん 6 例中 3 例 (50.0\%), 前立腺がん 8 例中 2 例 ( $25.0 \%)$, 甲状腺 がん 5 例中 1 例 (20.0\%) などであるが, 頻度として は菊屋の報告之同様に特に肺がんと腎がんの骨転移に 多い. 昭和 40 年12月末までの検討では既述のでとく, 肺がんが 10 例と圧倒的に多くなつており，ついで腎 がんが 5 例上約半数以上がこれらで占められている. 即ち, 原発巣不明のものがその臨床経過中あるいは剖 検で肺がんが原発と判明した症例が特に多い.

これら骨転移初発例患者の原発巣探索抢よび治療法 について倹討すれば,

\section{1. 腎がん}

A）骨転移巣のエックス線像が溶骨性で，特に四 肢長管骨の骨幹部に存在する時にはまず腎がんの骨転 移が疑われる。

B）診断法 逆行性腎孟造影, Aortography 飞 よる両腎臟の動脈撮影 $\rightarrow$ 選択的腎臟動脈撮影, 腎シン チグラムなどによる原発巣の探索抢よび骨転移巣の動 脈撮影および試験穿刺など各々が腎がんに特徽的で診 断は比較的容易である.

C）治療 全身状態が許せば原発巣の摘除を第一 とし，骨転移巣に対しては切断術，骨接合術，放射線 療法などを適切に実施する。

\section{2. 肺がん}


A）骨転移巣のエックス線像が腎がんの骨転移集 ほど純溶骨性でない時はまづ肺がんの骨転移を疑うべ きである。

B）診断法 肺の断層撮影, 気管支造影, 喀痰の 細胞診，肺の細胞診および組織診などが行なわれる。

C）治療 肺がんの術後起生率が未だ甚だ低率で ある現在，専ら骨転移を伴なう場合にはまづ放射線療 法, ついで化学療法が実施されるが，骨転移巣に対 してもやはり腎がん同様対症的に適切な処置を実施 する.

\section{3. 前立腺が $ん$}

A）骨転移巣のエックス線像が特徽的に骨形成性 で, 特に酸性ホスファターゼ值の増量が認められる時 は，まつ前立腺がんの骨転移が疑われる.

B）診断法 前立腺のバイオプシ一.

C）治療 除睪術，副腎摘除術，ホンバン投与な どのほか, 放射線療法が原発巣および骨転移栄に対し て非常に有効である.

以上が国立がんセンターにおける骨転移初発例患者 に対する治療の概況であるが, 最近 Mims (1966) は 特に腎がんではたとえ骨転移が認められる場合でも原
発巣を摘除すれば，骨転移坚む強力な自家免疫反応に よつて治癒すると推論して積極的な治療を提唱して いる.

以上，骨転移を初発症状としたがん患者について若 干の考察および検討を行つたが, 諸賢の御批判を戴け れば幸甚である。

\section{文献}

1) Geschickter, C. F. et al.: Tumors of Bone. 3rd ed. Philadelphia, J. B. Lippincott, 1949.

2) Graham, W. D. : Bone Tumours. London, Butterworths, 1966.

3）菊屋：転移性骨癌の臨床的統計的観察. 整形外 科. $11: 441-457$, 昭35.

4) Mims, M. M. et al.: Ten year evaluation of nephrectomy for extensive renal cell carcinoma. J. Urol., 95 : 10-15, 1966.

5)佐藤：がんの骨転移の診断に関する研究. 医学 研究. $36: 487-519$, 昭 41 .

6)池本：主として局胛骨に転移せる肺癌の 1 剖検 例. 整形外科. $17: 803-807$, 昭 41 .

7）入江：診断困難であつた癌の広沉性骨転移の1 例. 整形外科と災害外科. $15: 173-175$, 昭 41 . 